\title{
TEAM-BASED LEARNING AND GENERIC CAPABILITIES IN STUDENTS WITH AND WITHOUT EXPERIENCING THE INDONESIAN QUALIFICATION FRAMEWORK CURRICULUM- BASED: EVIDENCE FROM ACCOUNTING EDUCATION STUDENTS IN INDONESIA
}

\author{
Andri Zainal ${ }^{*}$, Wildanin Haurin Putri ${ }^{1}$, Venny Tritara Kartika ${ }^{1}$, Tuti Sriwedari ${ }^{1}$ \\ ${ }^{1}$ Department of Accounting Education, Faculty of Economics, Universitas Negeri Medan, Medan, Indonesia \\ *Corresponding Author: andrizainal@ unimed.ac.id
}

\begin{abstract}
Student skills should be able to be trained and developed during the learning process, especially generic skills. The purpose of this study is to analyze the effect of team-based learning on the generic abilities of accounting students at Medan State University. The population in this study were accounting education program students totaling 96 students from class of 2015 and 107 students from class of 2015. Data collection techniques using questionnaires. The validity, reliability, and classic assumption testing are employed before conducting hypothesis testing using a two samples t-test for difference of means. The results showed that there was an effect of the application of the Team-Based Learning (TBL) learning model on generic abilities in Accounting Education students.
\end{abstract}

Keywords: Team Based Learning, Generic Capabilities, Accounting Students, Universitas Negeri Medan.

\section{INTRODUCTION}

Higher education should be able to organize a quality learning process that not only develops the ability of students to be limited to one cognitive aspect, while other aspects, especially skills, are rarely touched. This has become one of the causes of the inability of tertiary education graduates to compete in the world of work or allow graduates to work in fields that are not relevant to their educational qualifications. Following the 2013 National Qualification Framework or abbreviated as KKNI in the Indonesian term, that tertiary graduates must be able to apply their fields of expertise and utilize science and technology in their fields in problem-solving and be able to adapt to the situation at hand, master the theoretical concepts of particular fields of knowledge in general and the theoretical concepts of individual sections in that field of knowledge in-depth, and able to formulate procedural problem-solving. Referring to what is written in the $2013 \mathrm{KKNI}$ in the implementation of learning in higher education, especially the aspects of skills, become one of the leading indicators of the success of an educational process.

Based on this, various student skills should be able to be trained and developed during the learning process, especially generic skills. Generic skills become one of the underlying assets for students, both while attending lectures and when they are in the workforce. According to Kamsah (2004), generic skills are employability skills that are used to apply knowledge. This skill crosses all fields of work in the horizontal direction and crosses all levels in the vertical direction. This definition is similar to that proposed by the National Skill Task Force (Pumphey and Slater (2002), that generic skills are skills that cross a number of different jobs. Kearns (Yeung et al., 2007) defines generic skills as skills and attributes for life, and Yeung et al. (2007) stated that generic skills are beneficial for continuing education and career success. From the various understandings given by some experts, it can be concluded that generic skills are skills needed for various fields of work and life.

Students Grade Point Average (GPA) at this time cannot be used as the primary indicator of graduates of a university to be able to compete in the world of work. Irma (2007) reports that the CPI ranks only 17th in indicators and abilities that reflect a person's quality. Other factors, for example, the ability to communicate, honesty and integrity, the ability to cooperate, analytical power, leadership, and others, play an essential role in the success of someone at work. From the survey results, it can be concluded that the world of work does not only require prospective workers who only 
have cognitive abilities but rather requires prospective workers who can apply their cognitive abilities in various forms of skills. The intended skills are generic/soft skills, employability skills.

Medan State University (UNIMED) is one of the state universities in North Sumatra. At present, UNIMED has implemented the KKNI curriculum for each generation except for the class of 2015. However, this also applies to students of the class of 2015 in the accounting education program. With the KKNI curriculum not being implemented for the class of 2015, the task load is relatively not as complex as the students in the class of 2016. Here the researcher takes the population of 2015 accounting education students who have not implemented the KKNI and 2017 brands who have implemented KKNI. This is to see whether the application of the curriculum can influence or not on the generic abilities to be studied. As we already know, the application of the KKNI-based curriculum in tertiary institutions is highly needed because it can hone the potential of students to become agents who are broad-minded and have skills that are by the criteria needed in the community, so here the researchers want to see how much influence. Financial Accounting is one of the compulsory courses in the Accounting Education Study Program, Faculty of Economics, State University of Medan. This course is used as a learning evaluation material in this study to find out how the influence of TBL on the generic abilities of students after attending the lecture process. This is based on the characteristics of this course, which in its implementation is almost $90 \%$ carried out with various activities which theoretically should be able to improve various generic skills of students.

Education in the 21st century is about how to build the intelligence of students through the use of learning models that can create more meaningful learning by training various skills as one aspect of the success of a learning process. The learning model in question is the TBL model. So far, users of TBL claim that there are various benefits gained by using the learning model, both in terms of teaching methodology and learning. TBL is better than traditional approaches (lecture-based learning) to obtain generic skills needed for scientific careers, such as collaboration, information integration, critical thinking, communication skills, and team-based learning (Dolmans et al. 2005). In short, there appears to be a close relationship between the opportunities provided by TBL to develop communication (teamwork and interpersonal), problem-solving and team-based learning, as well as critical thinking skills of other generic skills for graduates that can be utilized during lectures and even further when graduates enter the workforce.

Based on research conducted by Christensen et al (2018) it is known that TBL (Team Based Learning) helps educational outcomes and students' ability to apply team-based learning content (TBL). Students from introductory accounting courses are organized into permanent strategic teams and work in many activities in teams. TBL as a key pedagogical component of their learning activities. Compared with the control sample, it was shown that the TBL experience improved some attitudes, especially among quantitative students. After experiencing TBL, teamwork by students has increased, primarily related to cultural diversity. Students generally believe that their ability to perform the role of task leader, social-emotional leader and information provider significantly increases, as does the preference for performing two leadership roles.

\section{LITERATURE REVIEW}

\section{Theory of Social Constructivism}

The theory of social constructivism is a refinement of Piaget's cognitive constructivism that separates learning based on the context proposed by Vygotsky in 1978. Constructivism focuses on shifting paradigms to make students active in the learning process (Han \& Newell, 2014). What they do outside of class time are their responsibility and choice, but it will affect their learning achievement (Everaert et al., 2017). The theory of social constructivism deals with intrinsic motivation and students' extrinsic motivation in their learning activities. Which motivation influences the learning process? Is it intrinsic motivation or extrinsic motivation? Motivation in learning will determine what learning approach is applied and will affect learning achievement.

\section{Team Based Learning}

Clair and Chihara (2012) state that "Team-Based Learning is an effective teaching process that refers to the exercises conducted by students or the application of statistical concepts in class. With assignments given to students, either individual or group assignments, students are motivated to be better prepared to participate in group activities. Nanes (2014) states that "The use of learning with Team-Based Learning can remind students' thinking abilities." From the explanation above, it can be concluded that Team-Based Learning is an effective teaching process that refers to the exercises conducted by students or the application of statistical concepts in class. With assignments are given to students, both individual or group assignments can improve students' thinking abilities.

\section{Generic Capabilities}

Generic ability is essential for students because students need this ability to develop their future careers following their respective fields, especially in the field of accounting. Generic abilities are not obtained suddenly, but these abilities must be trained continuously to increase. Kenny et al. (2015) explain that "The generic ability of a concept is somewhat vague, but traditionally includes writing, verbal and interpersonal skills." Subsequently, Kenny et al. (2015) explained that "College of accounting graduates who have generic skills and are ready to work." Education and 
Manpower Bureau (2004) generic abilities are the basis for helping students how to learn. Generic abilities are developed through learning and teaching in the context of different subjects and areas and can be transferred into different learning situations. From the description above, it can be concluded that generic abilities are writing skills, verbal abilities, and interpersonal skills developed through learning and teaching in the context of different subjects and areas, and can be transferred into different learning situations.

\section{RESEARCH METHOD}

The population in this study consisted of 109 students of the batch of the 2015 and 96 students of the class of 2017 from the department of Accounting Education in the Faculty of Economics of UNIMED. We used a questionnaire to collect data about the implementation of TBL and the generic abilities of respondents. We conduct a two samples ttest for difference of means to test the hypothesis on diffrences on TBL and the generic abilities between accounting education students of batches 2015 and 2017.

\section{RESULT AND DISCUSSION}

The t-test of difference is used to determine whether two unrelated samples have different mean values.

\section{Team Based Learning (TBL)} Group Statistics

\begin{tabular}{|c|c|c|c|c|c|}
\hline & Year & $\mathrm{N}$ & Mean & $\begin{array}{l}\text { Std. } \\
\text { Deviation }\end{array}$ & $\begin{array}{l}\text { Std. Error } \\
\text { Mean }\end{array}$ \\
\hline Team Based Learning & 2015 & 85 & 16,36 & 0,949 & ,103 \\
\hline
\end{tabular}

Based on the "Group Statistics" output table above, it is known that the amount of TBL data for the 2015 class is 85 students, while for 2017, the are 77 students, both of them are out of 100. The average TBL or Mean value for the 2015 whip is 16.36 , while for the 2017 whip is 16.31 . Thus, descriptively statistically, it can be concluded that there is a difference in the average of TBL between the class of 2015 and 2017. Furthermore, to prove whether the difference is significant (real) or not, it is necessary to interpret the output of the "Independent Samples Test" below.

Independent Samples Test

\begin{tabular}{|c|c|c|c|c|c|c|c|c|c|c|}
\hline & & \multicolumn{2}{|c|}{\begin{tabular}{|l|}
\multicolumn{2}{|l|}{ Levene's } \\
Test for \\
Equality of \\
Variances \\
\end{tabular}} & \multicolumn{7}{|c|}{ t-test for Equality of Means } \\
\hline & & \multirow[b]{2}{*}{$\mathrm{F}$} & \multirow[b]{2}{*}{ Sig. } & \multirow[b]{2}{*}{$\mathrm{t}$} & \multirow[b]{2}{*}{$\mathrm{df}$} & \multirow{2}{*}{$\begin{array}{l}\text { Sig. } \\
(2- \\
\text { tailed } \\
)\end{array}$} & \multirow{2}{*}{$\begin{array}{l}\text { Mean } \\
\text { Differe } \\
\text { nce }\end{array}$} & \multirow{2}{*}{$\begin{array}{l}\text { Std. } \\
\text { Error } \\
\text { Differe } \\
\text { nce }\end{array}$} & \multicolumn{2}{|c|}{$\begin{array}{l}95 \% \text { Confidence } \\
\text { Interval of the } \\
\text { Difference }\end{array}$} \\
\hline & & & & & & & & & Lower & Upper \\
\hline $\begin{array}{l}\text { Team } \\
\text { Based }\end{array}$ & $\begin{array}{ll}\text { Equal } & \text { variances } \\
\text { assumed } & \end{array}$ & ,591 & ,443 & ,884 & 160 &, 037 & $-9,449$ & ,6238 &,- 6803 & $-1,7834$ \\
\hline Learning & $\begin{array}{l}\text { Equal variances not } \\
\text { assumed }\end{array}$ & & & ,887 & 159,702 &, 038 & $-9,449$ & ,6220 &,- 6769 & $-1,7800$ \\
\hline
\end{tabular}

Based on the above output, Sig. Levene's Test for Equality of Variances is $0.443>0.05$. It can be interpreted that the data variance between batches of 2015 and 2017 can be homogeneous or the same (Sujarweni, 2014). So the estimation of the Independent Samples Test output table above is based on the values contained in the "Equal variances assumed" table. Based on the "Independent Samples Test" output table in the "Equal variances assumed" section, the Sig. (2tailed) of $0.037<0.05$, then as the basis for decision making in the independent sample t-test, it can be concluded that Ho is rejected, and $\mathrm{H}$ is accepted. Thus, it can be concluded that there is a significant (real) difference between the average TBL in the classes of 2015 and 2017. Furthermore, from the output table above, known "Mean Difference" value is $-9,449$. This value shows the difference between the average TBL in the 2015 cane with the 2017 cane or $45,941-55,390=-9,449$.

\section{Generic Capabilities}

Group Statistics

\begin{tabular}{|c|c|c|c|c|c|}
\hline & Year & $\mathrm{N}$ & Mean & $\begin{array}{l}\text { Std. } \\
\text { Deviation }\end{array}$ & $\begin{array}{l}\text { Std. Error } \\
\text { Mean }\end{array}$ \\
\hline Generic Capabilities & $\begin{array}{l}2015 \\
2017\end{array}$ & $\begin{array}{l}85 \\
77\end{array}$ & $\begin{array}{l}45,941 \\
55,390\end{array}$ & $\begin{array}{l}4,0689 \\
3,8462\end{array}$ & $\begin{array}{l}, 4413 \\
4383\end{array}$ \\
\hline
\end{tabular}


Based on the "Group Statistics" output table above, it is known that the total number of Generic Ability data for the class of 2015 is 85 students, while for the 2017 class of is 77 students. The average value of Generic Capability or Mean for the 2015 class is 45,941 , while for 2017 , the score is 45,390 . Thus, in descriptive statistics, it can be concluded that there are differences in the average Generic Capability between the class of 2015 and 2017. Furthermore, to prove whether the difference is significant (real) or not, it is necessary to interpret the output of the "Independent Samples Test" below.

Independent Samples Test

\begin{tabular}{|c|c|c|c|c|c|c|c|c|c|c|}
\hline & \multicolumn{2}{|c|}{\begin{tabular}{|lr|}
\multicolumn{2}{|l|}{ Levene's } \\
Test for \\
Equality of \\
Variances \\
\end{tabular}} & \multicolumn{7}{|c|}{ t-test for Equality of Means } \\
\hline & & \multirow[b]{2}{*}{$\mathrm{F}$} & \multirow[b]{2}{*}{ Sig. } & \multirow[b]{2}{*}{$\mathrm{t}$} & \multirow[b]{2}{*}{ df } & \multirow{2}{*}{$\begin{array}{l}\text { Sig. } \\
(2- \\
\text { tailed } \\
)\end{array}$} & \multirow{2}{*}{$\begin{array}{l}\text { Mean } \\
\text { Differe } \\
\text { nce }\end{array}$} & \multirow{2}{*}{$\begin{array}{l}\text { Std. } \\
\text { Error } \\
\text { Differe } \\
\text { nce }\end{array}$} & \multicolumn{2}{|c|}{$\begin{array}{l}95 \% \text { Confidence } \\
\text { Interval of the } \\
\text { Difference }\end{array}$} \\
\hline & & & & & & & & & Lower & Upper \\
\hline $\begin{array}{l}\text { Generic } \\
\text { Capabilities }\end{array}$ & $\begin{array}{l}\text { Equal } \\
\text { assumed }\end{array}$ &, 591 & ,443 &, 884 & 160 &, 037 & $-9,449$ & ,6238 &,- 6803 & $-1,7834$ \\
\hline & $\begin{array}{l}\text { Equal variances not } \\
\text { assumed }\end{array}$ & & &, 887 & 159,702 & & $-9,449$ &, 6220 &,- 6769 & $-1,7800$ \\
\hline
\end{tabular}

Based on the above output, Sig. Levene's Test for Equality of Variances is $0.443>0.05$. It can be interpreted that the data variance between the 2015 canes and 2017 can be homogeneous or the same (Sujarweni, 2014). So, the interpretation of the Independent Samples Test output table above is based on the values contained in the "Equal variances assumed" table. Based on the "Independent Samples Test" output table in the "Equal variances assumed" section, the Sig. (2-tailed) of $0.037<0.05$, then as the basis for decision making in the independent sample t-test, it can be concluded that Ho is rejected, and $\mathrm{H}$ is accepted. Thus, it can be concluded that there is a significant (real) difference between the average TBL in the class of 2015 and 2017. Furthermore, from the output table above, known as "Mean Difference" value is $-9,449$. This value shows the difference between the average Generic Capability in the class of 2015 with the class 2017 or $45,941-55,390=-9,449.2$.

\section{Comparing score of t-count with t-table in the Independent Sample t-test Test}

The decision made on the comparison of the value of $t$ arithmetic with $t$ table in the independent sample $t$-test can be referred by the following basic decisions:

a. If the $\mathrm{t}$ value $<\mathrm{t}$ table, then Ho is accepted, and $\mathrm{Ha}$ is rejected, which means there is no difference in the average TBL with the generic abilities of students between the 2015 and 2017 batches.

b. If the value of $\mathrm{t}$ arithmetic $>\mathrm{t}$ table then Ho is rejected, and $\mathrm{Ha}$ is accepted, which means there is a difference in the average TBL with the generic abilities of students between the 2015 and 2017 batches (Jonathan, 2015)

The $t$-count value is 0.884 . Furthermore, $t$ table with the formula $(\alpha / 2) ;(d f)=(0.05 / 2) ;(160)=0.025 ; 160$. Then found t table value of 1.97490 . Thus, the $t$ value is $0.884>t$ table 1.97490 . It can be concluded that Ho is rejected and $\mathrm{Ha}$ is accepted, which means there is a difference in the average TBL against generic abilities between 2015 and 2017 classes.

\section{CONCLUSION}

Based on the results of research that have been carried out regarding the effect of TBL on the generic abilities of students in the accounting education study program in 2015 and 2017, with indicators used in this generic, including identifying writing skills, verbal (verbal) and interpersonal skills, it can be concluded that there is an influence of the TBL model on generic abilities in the 2015 and 2017. 2017 accounting education students. $0.00<0.05$, and the magnitude of the coefficient of determination ( $\mathrm{R}$ square) is 0.336 or equal to $33.6 \%$. In the class of 2017 , the value of sig. $0.010>0.05$, and the coefficient of determination (R square) is 0.084 or equal to $8.4 \%$. Generic ability is not the only factor that can improve the learning of TBL for students of accounting education in 2015 and 2017 FE UNIMED. Based on the Independent Sample t-test comparison test between the class of 2015 and 2017, it can be concluded that there is a difference in the average TBL to the generic ability between the 2015 cane and the 2017 cane. This can happen because there are more 2015 samples that are 85 people compared to the 2017 cane, which only numbered 77 people. Then it could also be caused by the seriousness of the respondents in answering the questions listed in the 
questionnaire while the research results are seen from the level of seriousness of respondents participating in answering each question.

\section{REFERENCES}

Christensen, J., Harrison, J. L., Hollindale, J., \& Wood, K. (2019). Implementing team-based learning (TBL) in accounting courses. Accounting Education, 28(2), 195-219.

Education and Manpower Bureau. (2004). Empowering learning and teaching with information technology. Hong Kong: Education and Manpower Bureau.

Irma, D. (2007). Soft Skill? Pikiran Rakyat, Kamis 17 Juni 2007. Retrieved from: https://aargantenk.multiply. com/journal/item/70/Soft_Skill

Kamsah, M. Z. (2004). Developing Generic Skills in Classroom Environment: Engineering Student's Perspective.

Kenny, P., McLaren, H., Blissenden, M., \& Villios, S. (2015). Improving the students' tax experience: A team-based learning approach for undergraduate accounting students. Journal of the Australasian Tax Teachers Association, 10(1), 43.

Pumphrey, J. \& Slater, J. (2002). An Assessmentof Generic Skill Needs. Notingham: Department for Education and Skills.

Sujarweni, V. Wiratna. 2014. Metodologi Penelitian. Yogyakarta: Pustaka Baru Press.

Tempone, I., Kavanagh, M., Segal, N., Hancock, P., Howieson, B., \& Kent, J. (2012). Desirable generic attributes for accounting graduates into the 21st Century: The views of employers. Accounting Research Journal, 25(1), 4155.

Yeung, A. S., Ng, Chistina, Liu, W. P. (2007). Generic Capabilities for Lifelong Education: Conceptualization and Construct Validity. Australian Association for Research in Education, Fremantle, November. 